\title{
Effect of siRNA targeting dengue virus genes on replication of dengue virus: an in vitro experimental study
}

\author{
Om Prakash ${ }^{1} \cdot$ Danish N. Khan $^{1} \cdot$ Turya Singh $^{1} \cdot$ Suruchi Shukla $^{1} \cdot$ \\ Shantanu Prakash ${ }^{1} \cdot$ Jain Amita $^{1}$
}

Received: 21 December 2020/Accepted: 20 May 2021/Published online: 28 August 2021

(C) Indian Virological Society 2021

\begin{abstract}
Dengue is a notorious viral infection, which affects a large segment of world populations in absence of vaccines and anti-viral treatment. The current study evaluates role of effective siRNA in dengue virus replication. Eight siRNA were synthesized against five different genes (Capsid, CprM, NS1, NS3 and NS5) of all serotypes of dengue virus. All serotype of DV were transfected with all synthesized siRNA in vitro, using BHK-21 cell lines. Culture fluid from test and control was tested by Real time PCR for CT value comparison in siRNA treated cell line (test) and untreated cell line (controls). Percent knockdown (\% KD) was calculated by $\Delta \Delta \mathrm{C}_{\mathrm{T}}$ methods to know the difference in test and control $\mathrm{CT}$ value. It was found that siRNA targeted against capsid gene worked best and showed inhibition of all four DV serotypes. DV-1, DV-2, DV-3 and DV-4 showed $93.8 \%, 99.3 \%, 87.5 \%$ and $93.8 \%$ knock down (\%KD) respectively by siRNA targeted against capsid gene. Additionally, Si2 (target CprM gene 60-899) and Si 6 (target NS1 gene 3007-3025) were also showing inhibition of replication. Most serotypes of DV (with few exceptions) were not inhibited by siRNA targeted against NS-1, NS-3, and NS-5 genes. Animal studies using siRNAs are warranted to establish their therapeutic role.
\end{abstract}

Keywords RNAi · siRNA · BHK-21 - DV · DMEM · Transfection $\cdot$ Knockdown

Jain Amita

amita602002@yahoo.com

1 King George's Medical University, Lucknow, Uttar Pradesh, India

\author{
Abbreviations \\ RNAi RNA interference \\ BHK-21 Baby hamster kidney cell \\ siRNA Small interfering RNA \\ DV Dengue virus \\ CPE Cytopathic effect \\ PBS Phosphate buffer saline \\ DMEM Dulbecco's Modified Eagle Medium
}

\section{Introduction}

Dengue virus (DV) infection is responsible for significant mortality and morbidity in world. Due to lack of effective strategy, scientists are unable to find specific remedy against it. Dengue virus is a mosquito borne, single, positive-strand RNA virus of the family Flaviviridae, genus Flavivirus [6]. Four known serotypes (DV 1-4) of the virus are circulating in India [8]. The viral genome is about 11,000 bases of single stranded RNA that codes for three structural protein, capsid protein C (114 Amino acids), membrane protein (166 Amino acids), envelope protein (495 amino acids) and seven non-structural proteins, NS1 (352 amino acid), NS2a (218 amino acid), NS2b (130 amino acid), NS3 (619 amino acid), NS4a (127 amino acid), NS4b (249 amino acid) and NS5 (899 amino acid). It also includes short non-coding regions on both the $5^{\prime}$ and $3^{\prime}$ ends.

All over the world multiple tools are being tried to manage dengue virus infection. RNAi (RNA interference) is one such strategy which has shown promising results in inhibiting other virus replication $[4,13]$. RNAi is sequence specific, effective gene silencing process that plays 
important role in defence against viruses [18]. Several studies have been done for prevention of dengue virus replication through RNAi [9, 25, 29]. RNAi works in cells by either suppressing transcription or by activating a sequence specific RNA degradation process. There are two important components of RNAi; miRNA and siRNA. siRNA (small interfering RNA) can be synthesized artificially, hence can be a successful tool in inhibiting viruses in vitro. Therefore, the present study was planned to study the effect of siRNA targeting five genes (Capsid, CprM, NS1, NS3 and NS3) of dengue virus genome on all four serotypes of dengue virus in vitro.

\section{Materials and methods}

\section{siRNA design and synthesis}

The nucleotide sequence of standard strains of all four DENV serotypes were retrieved from NCBI database (https://www.ncbi.nlm.nih.gov/genome/?term=dengue+ virus) with accession numbers; EU081255.1 (DV-1), FJ467493.1 (DV-2), KU216209.1 (DV-3) and KT794007.1 (DV-4). Selection of best possible siRNAs against the chosen target positions for all four DV serotypes were carried out with the help of I-score designer. It includes nine different siRNA designing scores of Ui-Tei, Amarzguioui, Hsieh'Takasaki, s-Biopredsi“ I-Score‘ Reynolds“ Katoh and DSIR (https://www.med.nagoyau.ac.jp/neurogenetics/i_Score/i_score.html) accessed on 20.3.2017. To design best possible siRNA, target sequences were also screened using Gene runner, siRNA scales, I-score designer and Reynolds's guidelines [21]. Eight best designed siRNA as shown in Table 1 were synthesized and purified by HPLC (synthesized by Ambion, USA). Negative control (Cat\#AM4611) siRNA was labeled with FAM and purified for visualization after transfection (synthesized by Ambion, USA).

Table 1 Nucleotide sequences of designed siRNA

\section{Cell lines maintenance and virus propagation}

BHK-21cells procured from the National Institute of virology, Pune, India were cultured in $25 \mathrm{~cm}^{2}$ cell culture flasks (Corning, USA) and routinely maintained at $37{ }^{\circ} \mathrm{C}$ in a $5 \% \mathrm{CO}_{2}$ incubator (New Brunswick, USA). Freshly low passaged BHK-21 cells were used in the experiment. Cells were passaged in mid-exponential phase of culture at every 3-4 days at a split ratio of 1:4 after treatment with $0.25 \%$ trypsin solution and fed with fresh $5 \mathrm{ml}$ complete cell culture medium containing minimum essential media (DMEM) supplemented with $10 \%$ FBS, $3.8 \mathrm{~g} / \mathrm{L}$ sodium bicarbonate, $100 \mathrm{U} / \mathrm{ml}$ penicillin, and $100 \mu \mathrm{g} / \mathrm{ml}$ streptomycin at $37{ }^{\circ} \mathrm{C}$ in $5 \% \mathrm{CO}_{2}$ [20]. Standard strains of Dengue serotypes 1-4 were procured from ATCC (10801 University Boulevard, Manassas, Virginia, USA) in $1 \mathrm{ml}$ Cryovials (NR-86-D4, NR-82-D2, NR-80-D3 and NR-84D1). All four dengue serotype were propagated in BHK-21 cells. For virus propagation, BHK-21 cells were inoculated with $200 \mu \mathrm{l}$ viral stock of 50PFU/ $\mu \mathrm{l}$ of standard strains of Dengue serotypes $1-4$. Post inoculation flasks were incubated for $2 \mathrm{~h}$ at $37{ }^{\circ} \mathrm{C}$ in a $5 \% \mathrm{CO}_{2}$ incubator to allow virus adsorption. Later, $5 \mathrm{ml}$ of maintenance medium was added and the flask was incubated in $5 \% \mathrm{CO}_{2}$ incubator at $37{ }^{\circ} \mathrm{C}$ and observed regularly to monitor the cytopathic effect (CPE). Once majority of cells showed CPE, virus titration was done by $\mathrm{TCID}_{50}$ and plaque assay [20]. Culture fluid was harvested and store at $-70{ }^{\circ} \mathrm{C}$.

\section{Transfection by FAM labeled siRNA}

To check the adaptability of BHK-21 cell lines for transfection, this experiment was done before transfection experiments. BHK21 cells were seeded over $22 \mathrm{~mm}$ round cover slips placed in wells of 6 well tissue culture plates (Nunc, USA). Plates were incubated at $37^{\circ} \mathrm{C}$ in a $5 \% \mathrm{CO} 2$ incubator to allow adherence and to reach $70-80 \%$ confluence of cells at the time of transfection. $1.5 \mu \mathrm{l}$

\begin{tabular}{llllll}
\hline S.No & Sequences $^{\prime}$ - $^{\prime}$ & Target gene & Position & Part no & Lot No \\
\hline si1 & UUUCUCUCGCGUUUCAGCAtt & Capsid & $60-401$ & $4,390,827$ & AS0295E1 \\
si2 & UCAAUAUCCCUGCUGUUGGtt & CprM & $60-899$ & $4,390,827$ & AS0295E2 \\
si3 & UCUAUCCAAUAGCCCAUGUtt & NS1 & $2385-3440$ & $4,390,827$ & AS0295E3 \\
si4 & UCCAACCUCCUCCAUAUGAtt & NS3 & $4485-6341$ & $4,390,827$ & AS0295E4 \\
si5 & AAAUGAGCCUCAUCCAUUAtt & NS3 & $4485-6341$ & $4,390,827$ & AS0295E5 \\
Si6 & UCCAAUAGCCCAUGUCAGCtt & NS1 & $3007-3025$ & $4,390,827$ & AS02EZ29 \\
Si7 & UGGAACAAACCACACUGUUtt & NS3 & $5592-5610$ & $4,390,827$ & AS02EZ30 \\
Si8 & AAUAUGACCAUCCUCCCCUtt & NS5 & $7819-7837$ & $4,390,827$ & AS02EZ31 \\
\hline
\end{tabular}


Lipofectamine $^{\mathrm{TM}} 3000$ (Invitrogen, USA) and $2 \mu \mathrm{l}$ FAM labeled negative control siRNA was added in a tube and kept at dark for 20 min to allow the siRNA-Lipofectamine complex formation. In the meantime, cells were rinsed thrice with serum free medium. The siRNA- Lipofectamine complex was overlaid on cells in an even manner and was incubated at $37^{\circ} \mathrm{C}$ for $2 \mathrm{~h}$ in a $\mathrm{CO}_{2}$ incubator. After this incubation transfection mixture was replaced with maintenance medium and plate was further incubated. Plate was taken out of the incubator after the completion of predetermined time period (at $24 \mathrm{~h}$, at $48 \mathrm{~h}$ and at $72 \mathrm{~h}$ ). Cover glass were removed from the culture wells after $24 \mathrm{~h}, 48 \mathrm{~h}$ and $72 \mathrm{~h}$ of incubation and examined to determine the minimum time taken for transfection. For examination cover slips were washed thrice with 0.05 M PBS (pH 7.4). Cells were fixed using chilled methanol. The dried cover slips were taken out and mounted onto $1 \mathrm{~mm}$ clean flat glass slides using mountant (65\% glycerol in PBS) and observed under a fluorescent microscope [34]. The successful transfection means at least $75 \%$ cells should show the fluorescence. Successful transfection was not achieved till $72 \mathrm{~h}$ of incubation; hence, further experiments were not terminated before $72 \mathrm{~h}$.

\section{Experimental design}

Five experimental groups were designed as per the details provided in Table 2. All experiments of transfection were done in 24 well plates with 70-80\% confluent BHK-21 cell lines. Each experiment was repeated in triplicate. Before the transfection experiments were setup, siRNA and Lipofectamine 3000 transfection reagent (Invitrogen, Thermo Fisher scientific, USA) were prepared for each experiment. Total $5 \mathrm{nM}$ of lyophilized commercially synthesized siRNA was suspended in $100 \mu \mathrm{l}$ of RNase free water to make $50 \mu \mathrm{M}$ Stock. Total $20 \mu \mathrm{l}$ of $50 \mu \mathrm{M}$ stock was diluted with $80 \mu \mathrm{l}$ RNase free water for preparation of working stock. $2 \mu \mathrm{l}$ of working siRNA, $96.5 \mu \mathrm{l}$ DMEM and $1.5 \mu \mathrm{l}$ Lipofectamine 3000 transfection reagents were used for each test and control well. Tubes with mix were lightly vortexed and incubated for 10-15 min. before use.

$100 \mu \mathrm{l}$ mixture solution of siRNA, Lipofectamine and DMEM was dispensed in each test and control wells containing 70-80\% of confluent cells as per plan shown in Table 2. Plates were kept at $37{ }^{\circ} \mathrm{C}$ in $5 \% \mathrm{CO}_{2}$ for $4 \mathrm{~h}$. After $4 \mathrm{~h}$ of incubation, the solution was removed and plates were washed by $1 \mathrm{X}$ PBS followed by addition of $250 \mu \mathrm{l}$ of $10 \%$ DMEM. Thereafter plates were incubated for $24 \mathrm{~h}$ at $37{ }^{\circ} \mathrm{C}$ in $5 \% \mathrm{CO}_{2}$. The plates were washed with $1 \times$ PBS and challenged with $200 \mu \mathrm{l}$ of each DV serotype of 50PFU/ $2 \mu \mathrm{l}$ [34]. Plates were then incubated for $2 \mathrm{~h}$ at $37{ }^{\circ} \mathrm{C}$ in $5 \%$ $\mathrm{CO}_{2}$. After $2 \mathrm{~h}$, all wells were washed with $1 \times$ PBS. Fresh $2 \%$ DMEM was added in all wells and incubated at $37{ }^{\circ} \mathrm{C}$ in $5 \% \mathrm{CO}_{2}$. Total $100 \mu \mathrm{l}$ culture fluid was removed from each well at $72 \mathrm{~h}$ for Real time PCR for CT value comparisons in siRNA treated wells (test) and untreated wells (controls).

\section{Quantitative Real Time PCR analysis for viral load}

RNA was extracted from culture fluid taken from test and control wells, by Qiagen kit (Valencia, CA, USA). The extracted RNA was subjected to real time RT-PCR. CDC (Centers for Disease Control and Prevention, Atlanta, Georgia, USA) approved primers and probe was used. Amplicons sizes were $112 \mathrm{bp}, 78 \mathrm{bp}, 74 \mathrm{bp}$ and $89 \mathrm{bp}$ respectively for D1, D2, D3 and D4 [23]. Amplification conditions were: 45 cycle of denaturation at $95{ }^{\circ} \mathrm{C}$ for $15 \mathrm{~s}$, annealing at $55{ }^{\circ} \mathrm{C}$ for $20 \mathrm{~s}$ and extension at $72{ }^{\circ} \mathrm{C}$ for $20 \mathrm{~s}$ using $7500 \mathrm{ABI}$ real time PCR machine (Applied Biosystems $^{\text {TM }} 7500$ Real-Time PCR Systems). Relative mRNA expression was calculated by using $\Delta \Delta \mathrm{C}_{\mathrm{T}}$ method [3]. Percent knockdown (\%KD) was calculated by subtracting

Table 2 Experimental groups tested for each serotype of dengue virus and each siRNA to study the virus inhibition by si RNA

\begin{tabular}{|c|c|c|}
\hline Group name & Experiment condition & Purpose \\
\hline TT (Test group) & $\begin{array}{l}\text { BHK-21 cell line transfected with dengue specific } \\
\text { siRNA + dengue virus }+ \text { Lipofectamine }\end{array}$ & To measure $\%$ inhibition of DV replication by siRNA \\
\hline $\begin{array}{l}\mathrm{CC} \text { (Cell line } \\
\text { control group) }\end{array}$ & BHK-21 cell line (No virus) (No siRNA) & To check cell line stability \\
\hline $\begin{array}{l}\mathrm{VC} \text { (Virus positive } \\
\text { control group) }\end{array}$ & $\begin{array}{l}\text { BHK-21 cell line infected with dengue virus (No } \\
\text { Lipofectamine) (No siRNA) }\end{array}$ & To ensure that virus is growing uninhibited \\
\hline $\begin{array}{l}\text { NC (Negative } \\
\text { control group) }\end{array}$ & $\begin{array}{l}\text { BHK-21 cell line transfected with non- specific scrambled } \\
\text { siRNA }+ \text { dengue virus }+ \text { Lipofectamine }\end{array}$ & $\begin{array}{l}\text { To rule out non- specific inhibition of DV replication by } \\
\text { any non- specific siRNA }\end{array}$ \\
\hline $\begin{array}{l}\text { TC (Transfection } \\
\text { control group) }\end{array}$ & $\begin{array}{l}\text { BHK-21 cell line }+ \text { Lipofectamine (No virus) + FAM } \\
\text { labeled siRNA }\end{array}$ & $\begin{array}{l}\text { To ensure direct cellular uptake by BHK- } 21 \text { cell line } \\
\text { distribution and localization of labeled siRNA }\end{array}$ \\
\hline
\end{tabular}


the normalized $\Delta \Delta \mathrm{C}_{\mathrm{T}}$ expression from 1 (defined by the level of expression for untreated sample) and multiplying by $100(\% \mathrm{KD})$.

$\% \mathrm{KD}($ Knockdown $)=\left(1-\Delta \Delta \mathrm{C}_{\mathrm{T}}\right) \times 100$.

\section{Statistical analysis}

All values were presented as mean \pm S.D. Statistical significance was evaluated using the two-tailed Mann-Whitney U-test; $\mathrm{P}<0.05$ was considered significant.

\section{Result and discussion}

\section{siRNA transfection}

Experiment showed successful transfection of FAM labeled siRNA in the cell line. Fluorescence was observed at $24 \mathrm{~h}, 48 \mathrm{~h}$ and $72 \mathrm{~h}$, with maximum FAM fluorescence was seen at $72 \mathrm{~h}$. Therefore all experiments were set up for maximum period of up to $72 \mathrm{~h}$ (Fig. 1).

\section{Inhibitory effect of siRNA on Dengue virus replication}

The details of inhibitory effect experiments are shown in Table 3. siRNA1 (target capsid gene 60-401) showed inhibition of all four serotype of DV replication in vitro (87.5-99.3\% knockdown). siRNA2 (target CprM gene 60-899) showed inhibition of DV-2 and DV-4 (range 93.6-98\% knockdown). There was limited inhibition of DV-1 and DV-3 replication (75\% knockdown). siRNA 3 (Target NS1 gene 2385-3440) showed only 50\% inhibition with DV-1 and DV-4 and 75\% knockdown with DV-2 \& DV-3. siRNA 4 (target NS3 gene 4485-6341) showed inhibition of DV-2 and DV-4 (range 96.9-98\% knockdown). There was limited inhibition of DV-1 $(75 \%$ knockdown) and DV-3 (50\% knockdown) replication. siRNA 5 (target NS3 gene 4485-6341) showed limited inhibition of DV-4 replication (75\% knockdown). There was no significant effect on DV-1, DV-2 and DV-3 replication (50\% knockdown). siRNA 6 (target NS1 gene 3007-3025) showed inhibition of DV-1 and DV-3 (range 87-96\% knockdown). There was limited inhibition of DV2 and DV-4 replication (75\% knockdown). siRNA 7 (target NS3 gene 5592-5610) showed limited inhibition of DV-1, DV-3 and DV-4 replication (75\% knockdown) and no significant effect on DV-2. siRNA 8 (target NS5 gene 7819-7837) showed inhibition of DV-2 and DV-3 (87\% knockdown). DV-1 and DV-4 showed only $75 \%$ knockdown (Table 3).

\section{Negative Control}
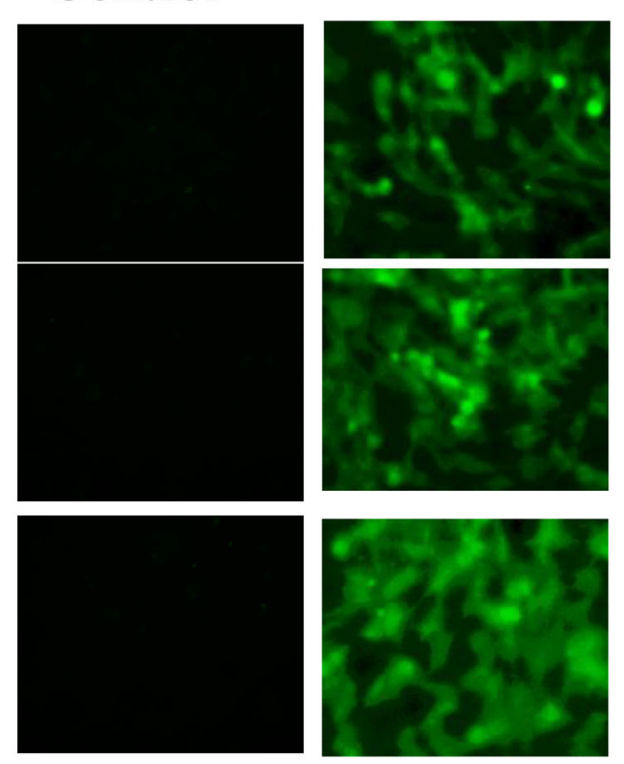
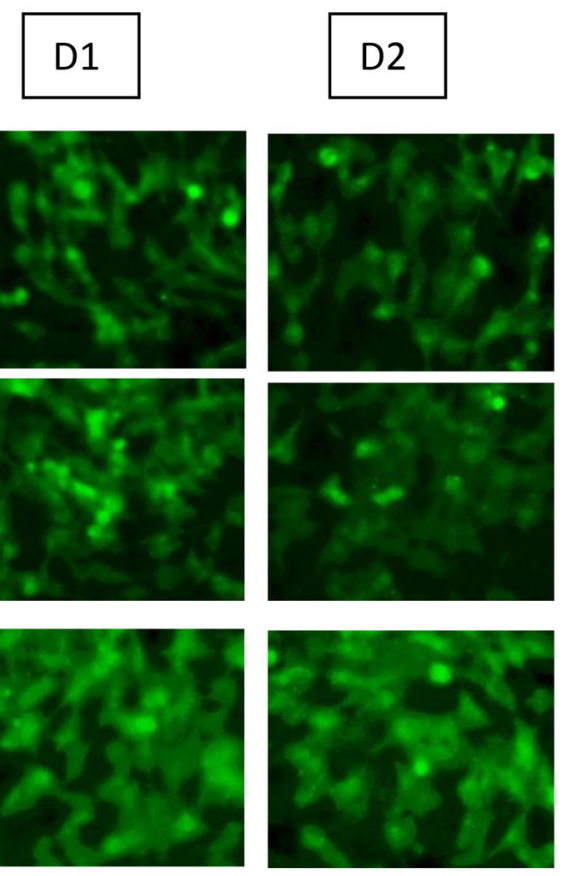
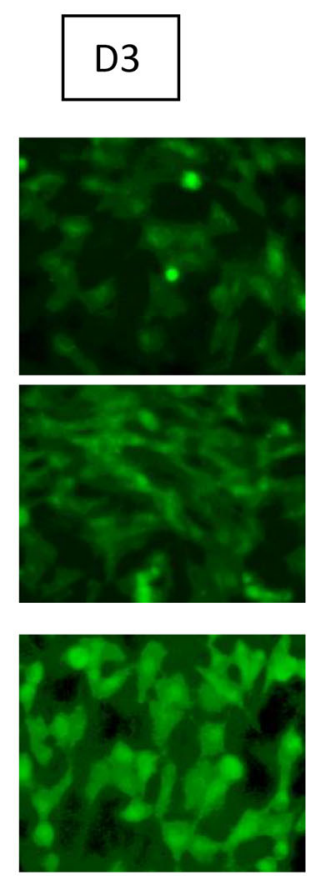
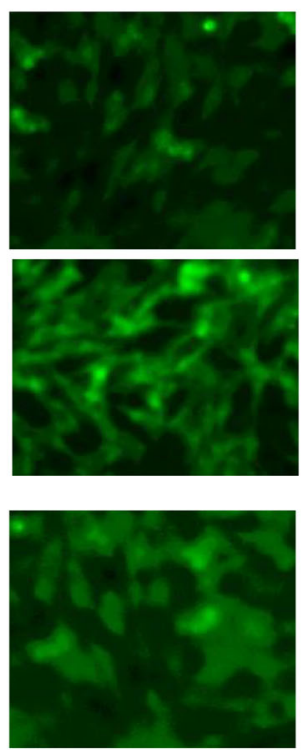

$24 \mathrm{hr}$

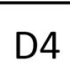

D4

$48 \mathrm{hr}$

$72 \mathrm{hr}$

Fig. 1 BHK-21 cells transfected with FAM-labeled control siRNA at $24 \mathrm{~h}, 48 \mathrm{~h}$ and $72 \mathrm{~h}$ 
Table 3 Percent inhibition of dengue virus replication in cells transfected with gene specific siRNA

\begin{tabular}{|c|c|c|c|c|c|c|c|}
\hline S.No & $\begin{array}{l}\text { SiRNA targeting gene/Position in } \\
\text { Genome }\end{array}$ & $\begin{array}{l}\text { DV } \\
\text { serotype }\end{array}$ & $\begin{array}{l}\text { TT(Test } \\
\text { group) }\end{array}$ & $\begin{array}{l}\text { VC(Virus } \\
\text { control) }\end{array}$ & $\begin{array}{l}\mathrm{NC}(\mathrm{Neg} \text { ative } \\
\text { control) }\end{array}$ & $\begin{array}{l}\Delta \mathrm{CT}=(\mathrm{TT}- \\
\mathrm{VC})\end{array}$ & $\begin{array}{l}\% \text { of Knockdown } \\
(\% \mathrm{KD})\end{array}$ \\
\hline \multirow[t]{4}{*}{1} & \multirow[t]{4}{*}{ Capsid gene (60-401) } & DV1 & $29.31 \pm 0.11$ & $25.31 \pm 0.11$ & $25.21 \pm 0.06$ & 4 & 93.8 \\
\hline & & DV2 & $28.4 \pm 0.15$ & $20.7 \pm 0.23$ & $20.16 \pm 0.10$ & 7.7 & 99.3 \\
\hline & & DV3 & $24.89 \pm 0.31$ & $21.2 \pm 0.23$ & $20.7 \pm 0.22$ & 3.6 & 87.5 \\
\hline & & DV4 & $27.6 \pm 0.19$ & $23.2 \pm 0.20$ & $23.1 \pm 0.12$ & 4.4 & 93.8 \\
\hline \multirow[t]{4}{*}{2} & \multirow[t]{4}{*}{ CprM gene (60-899) } & DV1 & $28.1 \pm 0.25$ & $25.2 \pm 0.21$ & $25.1 \pm 0.19$ & 2.7 & 75 \\
\hline & & DV2 & $27.5 \pm 0.16$ & $20.7 \pm 0.23$ & $20.2 \pm 0.10$ & 6.8 & 98 \\
\hline & & DV3 & $29.1 \pm 0.20$ & $28.1 \pm 0.17$ & $27.9 \pm 0.30$ & 2 & 75 \\
\hline & & DV4 & $27.5 \pm 0.20$ & $23.2 \pm 0.20$ & $23.1 \pm 0.26$ & 4.3 & 93.6 \\
\hline \multirow[t]{4}{*}{3} & \multirow[t]{4}{*}{ NS1 gene (2385-3440) } & DV1 & $25.0 \pm 0.310$ & $24.0 \pm 0.21$ & $24.1 \pm 0.32$ & 1 & 50 \\
\hline & & DV2 & $22.83 \pm 0.24$ & $20.7 \pm 0.21$ & $20.2 \pm 0.16$ & 2.1 & 75 \\
\hline & & DV3 & $24.4 \pm 0.19$ & $22.3 \pm 0.18$ & $22.1 \pm 0.19$ & 2.1 & 75 \\
\hline & & DV4 & $24.1 \pm 0.17$ & $23.2 \pm 0.15$ & $23.1 \pm 0.18$ & 0.9 & 50 \\
\hline \multirow[t]{4}{*}{4} & \multirow[t]{4}{*}{ NS3 gene (4485-6341) } & DV1 & $27.3 \pm 0.18$ & $25.3 \pm 0.18$ & $25.2 \pm 0.20$ & 2 & 75 \\
\hline & & DV2 & $26.2 \pm 0.15$ & $20.7 \pm 0.23$ & $20.4 \pm 0.15$ & 5.5 & 96.9 \\
\hline & & DV3 & $29.1 \pm 0.13$ & $28.1 \pm 0.15$ & $27.8 \pm 0.32$ & 1 & 50 \\
\hline & & DV4 & $30.0 \pm 0.22$ & $23.2 \pm 0.16$ & $23.1 \pm 0.18$ & 6.8 & 98 \\
\hline \multirow[t]{4}{*}{5} & \multirow[t]{4}{*}{ NS 3 gene (4485-6341) } & DV1 & $25.4 \pm 0.2$ & $24.3 \pm 0.16$ & $24.1 \pm 0.13$ & 1 & 50 \\
\hline & & DV2 & $21.5 \pm 0.31$ & $20.7 \pm 0.23$ & $20.5 \pm 0.15$ & 0.8 & 50 \\
\hline & & DV3 & $24.1 \pm 0.20$ & $23.2 \pm 0.15$ & $23.1 \pm 0.19$ & 0.9 & 50 \\
\hline & & DV4 & $25.7 \pm 0.25$ & $23.2 \pm 0.20$ & $23.1 \pm 0.11$ & 2.5 & 75 \\
\hline \multirow[t]{4}{*}{6} & \multirow[t]{4}{*}{ NS1 gene (3007-3025) } & DV1 & $24.4 \pm 0.17$ & $20.6 \pm 0.26$ & $20.9 \pm 0.29$ & 3.8 & 87 \\
\hline & & DV2 & $26.9 \pm 0.19$ & $24.4 \pm 0.2$ & $24.8 \pm 0.21$ & 2.5 & 75 \\
\hline & & DV3 & $25.8 \pm 0.13$ & $20.1 \pm 0.21$ & $20.4 \pm 0.16$ & 5.7 & 96 \\
\hline & & DV4 & $29.1 \pm 0.20$ & $26.2 \pm 0.15$ & $26.4 \pm 0.13$ & 2.9 & 75 \\
\hline \multirow[t]{4}{*}{7} & \multirow[t]{4}{*}{ NS3 gene (5592-5610) } & DV1 & $28.1 \pm 0.16$ & $25.2 \pm 0.2$ & $25.4 \pm 0.15$ & 2.9 & 75 \\
\hline & & DV2 & $29.1 \pm 0.14$ & $27.4 \pm 0.16$ & $27.3 \pm 0.21$ & 1.7 & 50 \\
\hline & & DV3 & $25.4 \pm 0.31$ & $22.8 \pm 0.13$ & $22.4 \pm 0.23$ & 2.6 & 75 \\
\hline & & DV4 & $22.4 \pm 0.17$ & $20.4 \pm 0.24$ & $20.6 \pm 0.2$ & 2 & 75 \\
\hline \multirow[t]{4}{*}{8} & \multirow[t]{4}{*}{ NS5 gene (7819-7837) } & DV1 & $22.4 \pm 0.16$ & $20.4 \pm 0.26$ & $20.6 \pm 0.19$ & 2 & 75 \\
\hline & & DV2 & $25.1 \pm 0.21$ & $21.8 \pm 0.19$ & $21.4 \pm 0.16$ & 3.3 & 87 \\
\hline & & DV3 & $23.4 \pm 0.17$ & $20.2 \pm 0.21$ & $20.4 \pm 0.23$ & 3.2 & 87 \\
\hline & & DV4 & $26.3 \pm 0.13$ & $23.4 \pm 0.25$ & $23.6 \pm 0.18$ & 2.9 & 75 \\
\hline
\end{tabular}

Data in bold denotes more than $85 \%$ knockdown

RNAi is believed to be an effective endogenous mechanism for host cells to defend against virus attack and has been applied as an exogenous measure to inhibit viral replication, such as HIV [15], influenza A virus [30], HBV [32] and SARS-CoV [26]. DV is one of the first animal viruses that could be efficiently inhibited by RNAi [31]. Some studies done on the siRNA against different target genes of DV in different cell lines/animals are listed in Table 4

In the present study, siRNA targeted against capsid gene (60-401 position) worked best and showed inhibition of replication all four DV serotypes (Table 3). Mature Capsid protein is highly basic protein of $12 \mathrm{KDa}$ [12]. N-Terminal region of DV capsid is involved in RNA binding and viral particle formation [22]. One previous study showed more than $98 \%$ inhibition of all DV serotypes using siRNA against Capsid gene in comparison to control siRNA. This study found that highly conserved sequence in DV capsid gene, if inhibited, can inhibit all DV serotypes in Huh-7 cell and DV-2 in AG129 mouse model [28].

In the present study siRNA against CprM gene was effective in inhibition only DV-2 and DV-4 serotype replication (Table 3). CprM, also termed as precursor membrane protein, comprises an $\mathrm{N}$ terminal domain, that is, predomain (part of membrane of an immature virus) followed by an $M$ domain, stem region, and two 
Table 4 Compiled results of previous studies showing target genes of Dengue viruses used for silencing/inhibition, cell lines used, techniques used for studying replication inhibition

\begin{tabular}{|c|c|c|c|c|c|}
\hline Year & $\begin{array}{l}\text { Cell lines/animals used in } \\
\text { experiments }\end{array}$ & $\begin{array}{l}\text { Targeted } \\
\text { DENV gene }\end{array}$ & $\begin{array}{l}\text { DENV serotype } \\
\text { tested }\end{array}$ & Method used to detect DENV infection & $\begin{array}{l}\text { Reference } \\
\text { No }\end{array}$ \\
\hline 2010 & $\begin{array}{l}\text { Human monocytes, DC and } \\
\text { macrophages }\end{array}$ & Envelope & DENV-2 & $\begin{array}{l}\text { Qualitative and quantitative RT-PCR, Flow } \\
\text { cytometry }\end{array}$ & 33 \\
\hline 2010 & $\mathrm{C} 6 / 36$ & $\mathrm{prM}$ & DENV-1 & MMT assay, Real time PCR & 8 \\
\hline 2011 & Huh-7 and Vero & Capsid protein & $\operatorname{DENV}(1-4)$ & $\begin{array}{l}\text { Immunoblots } \\
\text { Plaque assay } \\
\text { Cell viability assay } \\
\text { TNF measurement }\end{array}$ & 18 \\
\hline 2012 & Vero, BHK-21 and S2 & $3^{\prime} \mathrm{UTR}$ & DENV-2 & qRT-PCR & 34 \\
\hline 2012 & Vero & $5^{\prime} \mathrm{NTR}$ & $\operatorname{DENV}(1-4)$ & $\begin{array}{l}\text { DV NS1Ag } \\
\text { RT-PCR } \\
\text { Plaque assay }\end{array}$ & 23 \\
\hline 2013 & Huh-7 and HEK2937 & $\mathrm{NS} 4 \mathrm{~b}$ & DENV-2 & $\begin{array}{l}\text { qRT-PCR, Sequencing, IFN assay Protein } \\
\text { purification, Northern blotting }\end{array}$ & 35 \\
\hline 2018 & Vero and $\mathrm{C} 6 / 36$ & NS4b or NS5 & DENV (1-4) & Virtual hybridization program, other tools & 27 \\
\hline
\end{tabular}

transmembrane helices [16].There is a report to demonstrate that PrM gene of DENV-1 was successfully targeted by four synthetic siRNAs. siRNA were transfected in C6/ 36 cell line with DENV which showed reduced CPE (cytopathogenic effect) and increased cell survival by 2.26 fold. It also estimated reduction in viral RNA by about $97.54 \%$ in comparison to virus control group only at $7 \mathrm{dpi}$ (days post infection) [34].

In the present study, siRNA targeting NS1 gene was effective against DV-1 and DV-3 serotype. NS1 protein plays an important role in structural stability and secretion of NS1 in dimeric form [27] and have a role in immune evasiveness, viral replication, viral assembly, viral maturation and release [24]. NS3 protein is responsible for helicase and ATPase/RTPase activities, and should theoretically have role in DV replication [7]. To the best of our knowledge, this is the first report on the role of siRNA targeting NS3 gene, which was found to be effective against DV-2 and DV-4 serotypes only.

Both $5^{\prime}$ NTR and $3^{\prime}$ NTR have also been proven to be potential targets for siRNA technology. There are two sites (sh-3c and sh-5b) in $5^{\prime}$ NTR region which function as promoter for RNA synthesis. These sites with their complementary sequences in $3^{\prime} \mathrm{NTR}$ contribute interaction between two ends of genomic RNA. With the help of recombinant adenovirus -mediated expression of sh-5b siRNA, DV 1-4 were inhibited in Vero cell line depicting that $5^{\prime}$ NTR can be used as target to inhibit all four DV serotypes [14]. NS5 possess guanylyl transferase, guanine $\mathrm{N} 7$ methyltransferase and nucleoside $2^{\prime} \mathrm{O}$ methyltransferase activities required for $5^{\prime}$ RNA capping. It also helps virus in immune evasion [5, 17] and possess RNA dependent RNA polymerase (RdRp) activity for de novo synthesis of viral RNA [10]. In the present study siRNA targeting NS5 gene was effective against DV-1 and DV-4. In past small interfering RNAs (FG-siRNAs) targeting conserved sequences in the NS4B and NS5 regions of the DENV genome are shown to inhibit DENV replication. The FGsiRNAs were effective against DENV $-1,-3$, and -4 , but not DENV-2. siRNA specifically targeting the NS5 region of the DENV-2 genome (SG-siRNA) was designed and tested against two different DENV-2 strains, showing high levels of inhibition in both mammalian and insect cells [33].

The role of siRNA has been studied and proved to be effective for various viruses including West Nile virus (WNV), Japanese Encephalitis Virus (JEV), Influenza Virus, Human Immunodeficiency virus (HIV) etc. Jain et al. [11] identified siRNA that can be used as a universal therapeutic agent against anti-human Influenza virus. It showed $73.6 \%$ and $62.1 \%$ inhibition of Influenza A/pdm $\mathrm{H} 1 \mathrm{~N} 1$ and Influenza A/H3N2 respectively at $48 \mathrm{~h}$ post infection on MDCK cell line. The siRNAs targeting $\mathrm{M}$ gene have demonstrated effective inhibition of Influenza virus replication and provides a basis for the development of siRNA which can be used as universal anti-IAV therapeutic agent [11]. Studies done on the role of siRNA on Hepatitis $\mathrm{C}$ virus showed that siRNA targeted against $5^{\prime}$ untranslated region (5'UTR) of HCV genome achieved up to $80 \%$ suppression of replication. It also showed efficient delivery of RNAi into hepatocytes using DNA-based vectors, thereby demonstrating feasibility of siRNA based gene therapy in inhibiting HCV replication [35]. In a study 
on Chikungunya virus, the authors found a combination of siRNAs targeted against E2 and NS1 genes to have an additive effect leading to early and complete inhibition of virus replication in virus infected mice when administered $72 \mathrm{~h}$ post infection. They suggested that RNAi may constitute a novel therapeutic strategy for controlling CHIKV infection and transmission [19]. Similarly, siRNA targeting the NS5 gene showed significant antiviral activity against Japanese encephalitis virus infection in both cultured cells and mouse model [1]. siRNA activity was observed in neurons for shorter duration (3 weeks) and RVG9R-siFvEJW-treated animals succumbed to intracerebrally injected WNV a month after treatment. Thus, an effective siRNA reduced systemic exposure can be transformative for treating acute flavivirus neuroencephalitis, particularly in the elderly. This approach also offers better scope for strategic clinical testing in confirmed WNV disease [2].

Self life of siRNA is too short. siRNA molecules are only retained in $8.9 \%$ of the cells at the seventh day post transfection. Therefore, maintaining the continuity of RNA interference is crucial for the promotion and application of RNAi technology. There is no effectively vaccine or therapy for DV infection. In this scenario siRNA appears to be an attractive treatment modality, as it is safe chemotherapeutic agent because of its limited side effects and its specificity for viral genomes. However, limitations like lack of effective delivery mechanisms to reach target cells to knock out gene of interest.

In the present study, self-designed siRNA against Capsid gene effectively inhibited all serotypes of DV and appears promising. Additionally, results for siRNA against CprM and NS1 are also acceptable. These results provide a basis for further development of effective siRNA against Dengue virus.

Acknowledgements Authors acknowledge the Indian Council of Medical Research (ICMR), New Delhi, for providing financial support (Viral Diagnostic Lab Grant No. VIR/70/2013/ECD-1).

Funding Indian Council of Medical Research (ICMR), New Delhi.

\section{Declarations}

Conflicts of interest The author(s) declare that they have no competing interests.

Ethics approval 83rd ECM II A/P7 (No.1671/ethics/R.cell.-17) Registration no.ECR/262/inst/UP/3013 (dated 4.2.17).

\section{References}

1. Anantpadma M, Vrati S. siRNA-mediated suppression of Japanese encephalitis virus replication in cultured cells and mice. J Antimicrob Chemother. 2012;67(2):444-51. https://doi.org/10. 1093/jac/dkr487.
2. Beloor J, Maes N, Ullah I, Uchil P, Jackson A, Fikrig E, Lee SK, Kumar P. Small interfering RNA-mediated control of virus replication in the CNS is therapeutic and enables natural immunity to west Nile virus. Cell Host Microb. 2018;23(4):549-5563. https://doi.org/10.1016/j.chom.2018.03.001.

3. Bustin SA, editor. AZ of quantitative PCR. La Jolla, CA: International University Line; 2004-2006.

4. Castanotto D, Rossi JJ. The promises and pitfalls of RNA-interference-based therapeutics. Nature. 2009;22:426-33.

5. Chang DC, Hoang LT, Mohamed Naim AN, et al. Evasion of early innate immune response by $2^{\prime}$ Omethylation of dengue genomic RNA. Virology. 2016;499:259-66.

6. Chen R, Vasilakis N. Dengue-quo tu et quo vadis? Viruses. 2011;9:1562-660.

7. Clum S, Ebner KE, Padmanabhan R. Cotranslational membrane insertion of the serine proteinase precursor NS2B-NS3 (Pro) of dengue virus type 2 is required for efficient in vitro processing and is mediated through the hydrophobic regions of NS2B. J Biol Chem. 1997;272(49):30715-23.

8. Gupta N, Srivastava S, Jain A, Chaturvedi UC. Dengue in India. Indian J Med Res. 2012;136:373-90.

9. Idrees S, Ashfaq UA. RNAi: antiviral therapy against dengue virus. Asian Pac J Trop Biomed. 2013;3:232-6.

10. Issur M, Geiss BJ, Bougie I, et al. The flavivirus NS5 protein is a true RNA guanylyltransferase that catalyzes a two-step reaction to form the RNA cap structure. RNA. 2009;15(12):2340-50.

11. Jain B, Jain A, Prakash O, Singh AK, Dangi T, Singh M, Singh KP. In vitro validation of self designed "universal human Influenza A siRNA. Indian J Exp Biol. 2015;53(8):514-21.

12. Jones CT, Ma L, Burgner JW, Groesch TD, Post CB, Kuhn RJ. Flavivirus capsid is a dimeric alpha-helical protein. J Virol. 2003;77(12):7143-9.

13. Kakumani PK, Ponia SS, Sood V, Chinnappan M, Banerjea AC, Medigeshi GR, Malhotra P, Mukherjee SK, Bhatnagar RK. Role of RNA interference (RNAi) in dengue virus replication and identification of NS4B as an RNAi suppressor. J Virol. 2013;87(16):8870-83. https://doi.org/10.1128/JVI.02774-12.

14. Korrapati AB, Swaminathan G, Singh A, Khanna N, Swaminathan S. Adenovirus delivered short hairpin RNA targeting a conserved site in the $5^{\prime}$ non-translated region inhibits all four serotypes of dengue viruses. PLoS Negl Trop Dis. 2012;6:e1735.

15. Lee SK, Dykxhoorn DM, Kumar P, Ranjbar S, Song E, Maliszewski LE, François-Bongarçon V, Goldfeld A, Swamy NM, Lieberman J, Shankar P. Lentiviral delivery of short hairpin RNAs protects CD4 $\mathrm{T}$ cells from multiple clades and primary isolates of HIV. Blood. 2005;106(3):818-26. https://doi.org/10. 1182/blood-2004-10-3959.

16. Li L, Lok SM, Yu IM, et al. The flavivirus precursor membrane envelope protein complex: structure and maturation. Science. 2008;319(5871):1830-4.

17. Liu L, Dong H, Chen H, et al. Flavivirus RNA cap methyltransferase: structure, function and inhibition. Front Biol. 2010;5(4):286-303.

18. Obbard DJ, Gordon KH, Buck AH, Juggins FM. The evolution of RNAi as a defence against viruses and transposable elements. Philos Trans R Soc Lond B Biol Sci. 2009;364:99-115.

19. Parashar D, Paingankar MS, Kumar S, Gokhale MD, Sudeep AB, Shinde SB, Arankalle VA. Administration of E2 and NS1 siRNAs inhibit Chikungunya virus replication in vitro and protects mice infected with the virus. PLoS Negl Trop Dis. 2013;7(9):e2405. https://doi.org/10.1371/journal.pntd.0002405.

20. Phanthanawiboon S, A-nuegoonpipat A, Panngarm N, Limkittikul K, Ikuta K, Anantapreecha S, Kurosu T. Isolation and propagation of Dengue virus in Vero and BHK-21 cells expressing human DC-SIGN stably. J Virol Methods. 2014;209:55-61. 
21. Prakash O, Jain B, Jain A. Designing of putative siRNA to inhibit dengue virus replication. Int $J$ Res Dev Pharm Life Sci. 2018;7(5):3115-8.

22. Samsa MM, Mondotte JA, Caramelo JJ, Gamarnik AV. Uncoupling cis-acting RNA elements from coding sequences revealed a requirement of the $\mathrm{N}$-terminal region of dengue virus capsid protein in virus particle formation. J Virol. 2012;86(2):1046-58.

23. Santiago GA, Vergne E, Quiles Y, Cosme J, Vazquez J, Medina $\mathrm{JF}$, et al. Analytical and clinical performance of the CDC real time RT-PCR assay for detection and typing of dengue virus. PLoS Negl Trop Dis. 2013;7:7.

24. Scaturro P, Cortese M, Chatel-Chaix L, Fischl W, Bartenschlager R. Dengue virus non-structural protein 1 modulates infectious particle production via interaction with the structural proteins. PLoS Pathog. 2015;11(11):e1005277.

25. Schnettler E, Sterken MG, Leung JY, Metz SW, Geertsema C, Goldbach RW, Vlak JM, Kohl A, Khromykh AA, Pijlman GP. Noncoding flavivirus RNA displays RNA interference suppressor activity in insect and Mammalian cells. J Virol. 2012;86(24):13486-500. https://doi.org/10.1128/JVI.01104-12.

26. Shi Y, Yang DH, Xiong J, Jia J, Huang B, Jin YX. Inhibition of genes expression of SARS coronavirus by synthetic small interfering RNAs. Cell Res. 2005;15(3):193-200. https://doi.org/10. 1038/sj.cr.7290286.

27. Somnuke P, Hauhart RE, Atkinson JP, Diamond MS, Avirutnan P. N-linked glycosylation of dengue virus NS1 protein modulates secretion, cell-surface expression, hexamer stability, and interactions with human complement. Virology. 2011;413(2):253-64.

28. Stein DA, Perry ST, Buck MD, Oehmen CS, Fischer MA, Poore $\mathrm{E}$, et al. Inhibition of dengue virus infections in cell cultures and in AG129 mice by a small interfering RNA targeting a highly conserved sequence. J Virol. 2011;85:10154-66.

29. Subramanya S, Kim SS, Abraham S, Yao J, Kumar M, Kumar P, Haridas V, Lee SK, Shultz LD, Greiner DNM, Shankar P. Targeted delivery of small interfering RNA to human dendritic cells to suppress dengue virus infection and associated proinflammatory cytokine production. J Virol. 2010;84(5):2490-501. https:// doi.org/10.1128/JVI.02105-08.

30. Sui HY, Zhao GY, Huang JD, Jin DY, Yuen KY, Zheng BJ. Small interfering RNA targeting $\mathrm{m} 2$ gene induces effective and long term inhibition of influenza A virus replication. PLoS One. 2009;4(5):e5671. https://doi.org/10.1371/journal.pone.0005671.

31. Sánchez-Vargas I, Travanty EA, Keene KM, Franz AW, Beaty BJ, Blair CD, Olson KE. RNA silencing, arthropod-borne virus and mosquitoes. Virus Res. 2004;102:65-74.

32. Tang KF, Chen M, Xie J, Song GB, Shi YS, Liu Q, Mei ZC, Steinle A, Ren H. Inhibition of hepatitis B virus replication by small interference RNA induces expression of MICA in HepG2.2.15 cells. Med Microbiol Immunol. 2009;198(1):27-32. https://doi.org/10.1007/s00430-008-0101-6.

33. Villegas PM, Ortega E, Villa-Tanaca L, Barrón BL, Torres-Flores $\mathrm{J}$. Inhibition of dengue virus infection by small interfering RNAs that target highly conserved sequences in the NS4B or NS5 coding regions. Arch Virol. 2018;163(5):1331-5. https://doi.org/ 10.1007/s00705-018-3757-2.

34. Wu X, Hong H, Yue J, Wu Y, Li X, Jiang L, Li L, Li Q, Gao G, Yang $X$. Inhibitory effect of small interfering RNA on dengue virus replication in mosquito cells. Virol J. 2010;7(1):1-8.

35. Yokota T, Sakamoto N, Enomoto N, Tanabe Y, Miyagishi M, Maekawa S, Yi L, Kurosaki M, Taira K, Watanabe M, Mizusawa $\mathrm{H}$. Inhibition of intracellular hepatitis $\mathrm{C}$ virus replication by synthetic and vector-derived small interfering RNAs. EMBO Rep. 2003;4(6):602-8. https://doi.org/10.1038/sj.embor. embor840.

Publisher's Note Springer Nature remains neutral with regard to jurisdictional claims in published maps and institutional affiliations. 